\title{
Concomitant down-regulation of SPRY1 and SPRY2 in prostate carcinoma
}

\author{
S Fritzsche, M Kenzelmann ${ }^{1}, M$ J Hoffmann, M Müller, R Engers ${ }^{2}$, H-J Gröne ${ }^{1}$ \\ and $W$ A Schulz
}

Department of Urology, Heinrich-Heine University, Düsseldorf, Moorenstr. 5, 40225 Düsseldorf, Germany

${ }^{1}$ Department of Cellular and Molecular Pathology, German Cancer Research Centre, Im Neuenheimer Feld 280, 69120 Heidelberg,

Germany

${ }^{2}$ Department of Pathology, Heinrich-Heine University, Düsseldorf, Germany

(Requests for offprints should be addressed to W A Schulz; Email: wolfgang.schulz@uni-duesseldorf.de)

\begin{abstract}
Sprouty proteins encoded by the SPRY genes act as modulators and feedback inhibitors of signalling by epidermal growth factor (EGF) and fibroblast growth factor (FGF). Overactivity of EGF and FGF signalling common in prostate cancer might therefore be exacerbated by Sprouty down-regulation. Indeed, down-regulation of SPRY1 and SPRY2 expression has been independently reported. We found both genes modestly down-regulated by microarray expression analysis of microdissected prostate cancers and by quantitative RT-PCR in macrodissected specimens compared with benign tissues. Importantly, the decreases paralleled each other and expression levels of both genes were significantly lower in cancers that recurred within the average follow-up period of 32 months. In contrast to a previous report, no hypermethylation was found to accompany down-regulation of SPRY2 in cancer tissues and cell lines. We additionally investigated the expression of an SPRY1 alternative transcript presumed to be specific for fetal tissues and found its expression moderately well correlated with expression of the standard transcript through diverse tissues and cell lines. The present study confirms and extends previous reports by demonstrating concomitant down-regulation and a significant association with recurrence of SPRY genes.
\end{abstract}

Endocrine-Related Cancer (2006) 13 839-849

\section{Introduction}

As in many other carcinomas, growth factor signalling through receptor tyrosine kinases is activated in prostate cancer (Djakiew 2000, Blackledge 2003, Cronauer et al. 2003, Kwabi-Addo et al. 2004a). Several growth factors of the epidermal growth factor (EGF) and fibroblast growth factor (FGF) families are implicated acting by autocrine and paracrine mechanisms. Intracellularly, EGF and FGF signals are transmitted prominently through the canonical MAPK (mitogen-activated protein kinase) pathway. In normal cells, growth factors initiate numerous mechanisms in parallel with MAPK activation that limit the strength and duration of pro-proliferative signals. One such mechanism comprises induction and phosphorylation of sprouty (SPRY) proteins, which modulate growth factor signalling through receptor tyrosine kinases in a complex fashion (Hanafusa et al. 2002, Christofori 2003).
Modulation of growth factor signalling by SPRY proteins is particularly important during fetal development in shaping tissues and organs, including those of the urinary tract (Chi et al. 2004). In fact, the designation 'sprouty' derives from a Drosophila mutant displaying deficiencies in organ development (Hacohen et al. 1998). In humans, four SPRY genes are known (SPRY1-SPRY4), which are expressed in a tissue-specific fashion. In many adult tissues, SPRYI and $S P R Y 2$ are deemed most important. Recently, a novel alternative SPRYI mRNA has been reported to represent a fetal isoform (Wang et al. 2003). It differs from the standard transcript by an alternative noncoding exon 1 arising through alternative promoter use. We suggest the name $S P R Y 1 b$ to distinguish it from the standard transcript SPRYIa.

SPRY1 and SPRY2 proteins modulate signalling from tyrosine receptor kinases through RAS and MAP kinases and exert overall similar effects on FGF 
signalling, but differ in their influence on EGF signalling (Gross et al. 2001, Egan et al. 2002, Wong et al. 2002, Yusoff et al. 2002, Li et al. 2004). They disrupt the interaction between FGF receptors and the adaptor protein GRB2 and block activatory phosphorylation of RAF. However, SPRY2 in particular is not a pure feedback inhibitor, but also prolongs signalling by the EGF receptor under some circumstances.

Enhanced signalling by EGF and FGF family members in cancer ought to lead to an accordingly strong induction of MAPK pathway feedback inhibitors including SPRY mRNAs and proteins. Since this induction should impede cancer growth, one would expect selection to favour SPRY down-regulation, thereby exacerbating the tumourigenic effects of enhanced growth factor signalling. In contrast, oncogenic mutations of RAS or BRAF activate MAPK signalling downstream of SPRY action. Accordingly, SPRY2 has been reported as becoming induced in melanoma cell lines carrying such mutations (Bloethner et al. 2005). In prostate and breast cancers RAS mutations are rare and, indeed, evidence for downregulation of SPRY expression has been published (Kwabi-Addo et al. 2004b, Lo et al. 2004, McKie et al. 2005). However, several issues are unresolved.

$S P R Y 1$ and SPRY2 were reported to be downregulated in prostate cancer in two separate publications. The relation between the two genes has not been determined, i.e. are they down-regulated co-ordinately, as reported in breast cancer, or independently of each other? The degree of down-regulation reported was only moderate. Therefore, independent confirmation seems warranted. The alternative splice form of $S P R Y 1 \mathrm{mRNA}$ $(S P R Y 1 b)$ has not been investigated in cancers. Specifically, it is not known whether down-regulation of the presumed adult mRNA form is accompanied by up-regulation of the fetal isoform. Additionally, the role of epigenetic mechanisms such as DNA hypermethylation in SPRY down-regulation is unclear. In breast cancer, down-regulation did not appear to be associated with altered methylation, whereas in prostate cancer partial hypermethylation of $S P R Y 2$, but none of $S P R Y 1$, was reported. These questions were therefore addressed in the present study.

\section{Materials and methods}

\section{Laser-controlled microdissection}

RNase-free glass slides were prepared by baking at $200{ }^{\circ} \mathrm{C}$ for $4 \mathrm{~h}$ followed by covering with a PEN membrane (P.A.L.M. GmbH, Bernried, Germany). Frozen tissues were cut into $8 \mu \mathrm{m}$ sections, mounted onto the PEN membrane and haematoxylin and eosin stained. Laser-controlled microdissection on up to 30 000 epithelial cells each from histological hyperplasia, prostatic intraepithelial neoplasia and cancerous samples was performed using the P.A.L.M. microlaser technology (P.A.L.M. GmbH) according to the manufacturer's protocol. Total RNA was extracted from microdissected cells according to a standard method (Chomczynski \& Sacchi 1987) and RNA quality was checked using the RNA6000 nanoassay on the Bioanalyzer 2100 Lab-On-A-Chip system (Agilent Technologies, Palo Alto, CA, USA). RNA yields were usually $>200 \mathrm{ng}$ per sample.

\section{RNA amplification and microarray analysis}

Linear T7 polymerase-based amplification of total RNA from microdissected samples was performed essentially as previously described by Kenzelmann et al. (2004). RNA samples were then hybridized to HG U133A GeneChips (Affymetrix, Berlin, Germany) according to the manufacturer's instructions. Statistical analysis and data mining were performed with the software package MicroArray Solution, version 1.0, from SAS (SAS Institute, Minneapolis, MN, USA). GeneChip hybridization quality was controlled by correlation analysis; normalization of data and data mining were performed using log-linear mixed models with Bonferroni corrections that were fitted for values of perfect-matches, and by mixed model ANOVA (Cui \& Churchill 2003).

\section{Tissues for RT-PCR and methylation analyses}

Prostate carcinoma (PCa) specimens were obtained between 1997 and 2002 by radical prostatectomy. Cancerous and morphologically normal areas of the prostate were identified and specimens collected by a pathologist, rapidly frozen in liquid nitrogen and stored at $-80{ }^{\circ} \mathrm{C}$. Since several micrograms of high molecular weight DNA as well as sufficient amounts of RNA were prepared from the same sample, no microdissection was performed. Representative samples of $3 \mathrm{~mm}$ maximal diameter of tumour and tumour-free tissue specimens were collected, immediately snap frozen in liquid nitrogen and stored at $-80^{\circ} \mathrm{C}$. Non-cancerous tissue samples were taken from areas of the transition zone as far away as possible from the grossly apparent tumour (i.e. in general, from the transition zone of the contra-lateral lobe). Tumour and matched tumour-free specimens were only collected first when tumours were grossly apparent in the peripheral zone and could be unequivocally identified by their characteristic yellow or orangeyellow colour and secondly when the transition zone was macroscopically free of tumour. Separation 
between tumour and non-tumourous tissues was histologically verified by analysing tissue specimens immediately adjacent to the specimens collected for analysis. Tumour node metastases (TNM) classification was performed according to the guidelines of the International Union Against Cancer from 1997. Clinical data are summarized in Table 1. Of 49 prostate carcinoma tissues, 23 were staged as pT2, 24 as pT3, and 2 as pT4. Lymph node metastases were present in 10 patients. None of the patients had detectable distant metastases at the time of surgery. Fifteen tumours had Gleason scores $\leq 6,26$ tumours scores of 7 , and 8 tumours scores of $8-10$. Median patient age was 68 years, ranging from 55 to 76 years. The median follow-up period was 66 months (range 44-130). The study was approved by the Ethics Committee of the Heinrich Heine University medical faculty.

\section{Cell line cultivation and treatment}

The prostate carcinoma cell lines 22Rv1, LNCaP, PC3 and Du145 were cultured in RPMI-1640 (Gibco Life Technologies), supplemented with $10 \%$ fetal calf serum and $100 \mu \mathrm{g} / \mathrm{ml}$ penicillin/streptomycin. Normal uroepithelial cells (UC) were cultured as described (Swiatkowski et al. 2003). For experiments using 5-aza-2'-deoxycytidine (5-aza-dC), the compound (Sigma) was used at a concentration of $2 \mu \mathrm{M}$ every $24 \mathrm{~h}$ for 3 days. Treated and untreated cells, which received solvent only, were cultured in parallel until RNA extraction.

\section{RNA isolation and RT-PCR}

Total mRNA was isolated from cell cultures grown to $80 \%$ confluence, using the RNeasy Midi Kit (Qiagen). For tissues the same kit was used following guanidinium/acid phenol/chloroform extraction (peqGOLD TriFast, peqLab, Erlangen, Germany). Following photometric quantification, $2 \mu \mathrm{g}$ mRNA was transcribed into first strand cDNA using SuperscriptII (Invitrogen) according to the manufacturer's protocol with oligo-dT primers. Real-time PCR assays were performed using a fluorescence-detecting temperature cycler (LightCycler; Roche Diagnostics, Mannheim, Germany). The amplification mixture consisted of $1 X$ reaction mix (LightCycler-FastStart DNA Master PLUS SYBR Green I; Roche), 10 pmoles of each primer (see Table 2 for sequences and annealing temperatures) and $20 \mathrm{ng}$ cDNA in a final volume of $10 \mu \mathrm{l}$. The generation of target amplicons for each sample was monitored between the annealing and elongation steps at $640 \mathrm{~nm}$. After the final cycle, melting-point analysis of the samples was performed
Table 1 Tumour sample characteristics

\begin{tabular}{|c|c|c|c|c|}
\hline $\begin{array}{l}\text { Sample } \\
\text { number }\end{array}$ & $\begin{array}{l}\text { Patient } \\
\text { age }\end{array}$ & Stage & $\begin{array}{l}\text { Lymph node } \\
\text { status }\end{array}$ & Gleason score \\
\hline 36 & 72 & pT3b & pNO & 7 \\
\hline 38 & 75 & pT2b & pNO & 7 \\
\hline 50 & 67 & pT3b & $\mathrm{pN} 1$ & 7 \\
\hline 65 & 62 & pT3b & pNO & 7 \\
\hline 83 & 76 & рT3b & pNO & 7 \\
\hline 87 & 62 & рТЗа & pNO & 8 \\
\hline 89 & 68 & $\mathrm{pT} 2 \mathrm{~b}$ & pNO & 3 \\
\hline 93 & 73 & рT3b & pNO & 7 \\
\hline 95 & 74 & pT3b & pN1 & 10 \\
\hline 97 & 71 & рT3a & pNO & 7 \\
\hline 99 & 67 & pT2b & pNO & 5 \\
\hline 105 & 59 & рT3a & pNO & 5 \\
\hline 107 & 59 & рT3a & pNO & 7 \\
\hline 117 & 68 & pT3b & pNO & 5 \\
\hline 121 & 65 & pT2b & pNO & 6 \\
\hline 123 & 58 & pT2a & pNO & 5 \\
\hline 125 & 69 & pT2b & pNO & 6 \\
\hline 127 & 71 & pT2b & pNO & 6 \\
\hline 133 & 72 & pT2b & pN1 & 7 \\
\hline 137 & 73 & pT2b & pNo & 8 \\
\hline 139 & 65 & pT3b & pN1 & 9 \\
\hline 141 & 69 & $\mathrm{pT} 2 \mathrm{~b}$ & pNo & 4 \\
\hline 145 & 70 & pT4 & pN1 & 7 \\
\hline 157 & 58 & рT2 & pNo & 8 \\
\hline 161 & 64 & pT2b & pNo & 5 \\
\hline 163 & 65 & рТЗа & $\mathrm{pN} 1$ & 5 \\
\hline 169 & 72 & рТЗа & pNo & 7 \\
\hline 171 & 61 & $\mathrm{pT} 2 \mathrm{~b}$ & pNo & 5 \\
\hline 175 & 73 & $\mathrm{pT} 2 \mathrm{~b}$ & pNo & 8 \\
\hline 183 & 67 & рT3a & pNO & 6 \\
\hline 187 & 68 & pT2b & pNO & 8 \\
\hline 189 & 63 & $\mathrm{pT} 2 \mathrm{~b}$ & pNo & 7 \\
\hline 191 & 72 & pT2b & pNO & 7 \\
\hline 205 & 73 & рТ3a & pNO & 7 \\
\hline 209 & 71 & рТЗа & pNo & 7 \\
\hline 213 & 59 & pT2a & pNO & 7 \\
\hline 215 & 58 & рТ3a & pNO & 7 \\
\hline 217 & 62 & pT2b & pNo & 8 \\
\hline 219 & 64 & pT4 & pNO & 7 \\
\hline 225 & 62 & pT3b & pNO & 6 \\
\hline 227 & 72 & pT2a & $\mathrm{pN} 1$ & 7 \\
\hline 230 & 68 & pT2a & pNO & 7 \\
\hline 232 & 70 & pT2b & pN1 & 7 \\
\hline 236 & 74 & рT3a & pNo & 7 \\
\hline 238 & 62 & pT2a & pNO & 6 \\
\hline 245 & 66 & рТЗа & pNO & 7 \\
\hline 247 & 55 & pT3b & $\mathrm{pN} 1$ & 7 \\
\hline 253 & 61 & рT3a & pN1 & 7 \\
\hline 256 & 71 & рT3b & pNo & 7 \\
\hline
\end{tabular}

over the range of $69-99^{\circ} \mathrm{C}$. Turning-point values for the specific genes were related to those for $\beta$-actin or CK18.

\section{DNA extraction and bisulphite sequencing}

High molecular weight genomic DNA from tissue, cell lines and whole blood was isolated using the blood and 
Table 2 Primers used

\begin{tabular}{|c|c|c|c|c|}
\hline Designation & Sequence $\left(5^{\prime} \rightarrow 3^{\prime}\right)$ & $T_{M}\left({ }^{\circ} \mathbf{C}\right)$ & $\begin{array}{c}\text { Annealing } \\
T_{M}\left({ }^{\circ} \mathrm{C}\right)\end{array}$ & $\begin{array}{c}\text { Amplicon } \\
\text { size (bp) }\end{array}$ \\
\hline SPRY1a S & GTG TGT TGG AAA TCC ACG GT & 57.3 & 62 & $171 \mathrm{bp}$ \\
\hline SPRY1a AS & AAA GAA GGC TGC TGG ATC AC & 57.3 & & \\
\hline SPRY2 S & GAT TGC TCG GAA GTT GGT CT & 57.3 & 64 & $168 \mathrm{bp}$ \\
\hline SPRY2 AS & GGT CAC TCC AGC AGG CTT AG & 61.4 & & \\
\hline Aktin S & TGA CGG GGT CAC CCA CAC TGT GCC CAT CTA & 69.1 & 65 & $661 \mathrm{bp}$ \\
\hline Aktin AS & CTA GAA GCA TTT GCG GTG GAC GAT GGA GGG & 70.9 & & \\
\hline CK $18 \mathrm{~S}$ & AGT CTG TGG AGA ACG ACA TCC & 67.2 & 61 & $312 b p$ \\
\hline CK 18 AS & TGG TGC TCT CCT CAA TCT GC & 65.1 & & \\
\hline SPRY1b S & CGC TGT TAA ATG TGC CTG AA & 55.1 & 61 & $162 \mathrm{bp}$ \\
\hline SPRY1b AS & AAA GAA GGC TGC TGG ATC AC & 57.3 & & \\
\hline GAPDH $350 S$ & TCC CAT CAC CAT CTT CCA & 53.7 & 59 & 379 bp \\
\hline GAPDH 350AS & CAT CAC GCC ACA GTT TCC & 56.0 & & \\
\hline SPRY1a S bisulphite DNA & CAT CAC CAT CTT AAG GAT CAC & 55.9 & 54 & $319 b p$ \\
\hline SPRY1a AS bisulphite DNA & AAG AAC TTG TTT TCA TTC ATA AC & 51.7 & & \\
\hline SPRY2 S bisulphite DNA & GGT AGG AT(CT) GGT TTG GGG A & 57.7 & 55 & $160 \mathrm{bp}$ \\
\hline SPRY2 AS bisulphite DNA & AAC AAT TAT TAT CCC AAA AAA TAT ATC & 52.8 & & \\
\hline
\end{tabular}

cell culture DNA kit (Qiagen) with additional proteinase $\mathrm{K}$ treatment. Following bisulphite treatment using the CpGenome DNA Modification Kit (Q-Biogene, Eschwege, Germany), 80 ng of bisulphite-treated DNA were used for amplification by HotStar Taq polymerase (Qiagen) in a $50 \mu \mathrm{l}$ reaction with 20 pmoles of each primer indicated in Table 2. Following $15 \mathrm{~min}$ initial denaturation at $95^{\circ} \mathrm{C}, 36$ cycles of $30 \mathrm{~s}$ at $95^{\circ} \mathrm{C}, 30 \mathrm{~s}$ at the annealing temperature and $45 \mathrm{~s}$ at $72{ }^{\circ} \mathrm{C}$ were performed, with a final 10 min elongation. Q-solution (Qiagen) was added for SPRY2 amplification. PCR products were separated by $2.5 \%$ agarose gel electrophoresis and cloned into the TA-vector of the TOPO TA Cloning Kit (Invitrogen). Plasmid DNA was prepared from several clones for each cell line and sequenced by standard methods.

\section{Immunohistochemistry}

Immunohistochemistry using the avidin-biotinylated enzyme complex (ABC) method was performed essentially as described by Cohen et al. (2002) using a rabbit polyclonal antibody against SPRY2 (07-524, Upstate/Biomol, Hamburg, Germany).

\section{Results}

\section{SPRY1 and SPRY2 are co-ordinately but modestly down-regulated in prostate cancer}

In order to study the expression patterns of SPRY1 and SPRY2 along with prostate cancer development, HG U133A Affymetrix GeneChip microarray-based analyses were performed on histopathologically confirmed laser-controlled microdissected epithelial cells of
7 human hyperplastic tissues, 6 tissues showing severe prostatic intraepithelial neoplasia (PIN III; a precancerous lesion), and 7 tissues of prostate cancer, respectively. Microarray results for $S P R Y 1$ and $S P R Y 2$ revealed a gradual and co-ordinated down-regulation of both mRNAs from hyperplasia to PIN and prostate cancer, with $S P R Y 1$ being more abundantly expressed (Fig. 1). However, due to tissue-inherent individual differences in the expression intensity of both genes the down-regulation was not statistically significant $(P>0.05)$. Since the microarray oligonucleotide probe

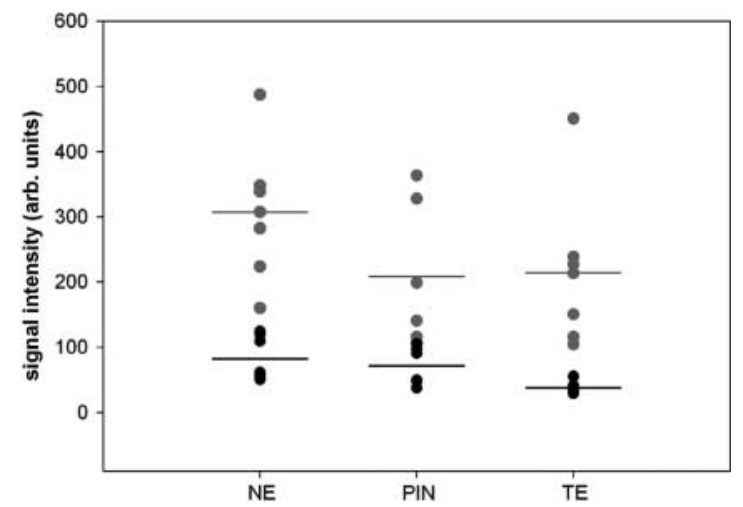

Figure 1 Analysis of $S P R Y 1$ and $S P R Y 2$ expression in prostate cancer development by microarray hybridisation. Distribution of the signal intensity values (arbitrary values) of SPRY1 and $S P R Y 2$ within microdissected human prostate tissues according to microarray analysis. Both genes are gradually and coordinately, but moderately down-regulated along with disease progression. Signal intensities for SPRY1 and SPRY2 in individual samples are shown in grey or black, respectively; mean expression values for each gene are also indicated. NE, hyperplastic (normal) epithelia; PIN, prostatic intraepithelial neoplasia; TE, tumour epithelia. 
set for SPRY1 does not distinguish between the two $S P R Y 1$ isoforms ( $l a$ and $l b)$, it cannot be decided whether the expression signal belongs to only one isoform or to a cumulative detection of both isoforms.

Since the decreases in SPRY expression determined in this experiment were rather moderate, we attempted to confirm down-regulation of the genes by quantitative real-time RT-PCR in an independent, larger series of 49 macrodissected prostate cancer samples and 9 non-cancerous tissues (Fig. 2). KRT18 (CK18) was used as a reference gene to adjust for the epithelial content in normal and cancerous prostate samples (Kwabi-Addo et al. 2004b). SPRYla expression was not significantly lower in cancerous than in noncancerous tissues, whereas the SPRY2/CK 18 expression ratio was significantly decreased in the cancer tissues $(P=0.017)$. Importantly, expression of $S P R Y 1 a$ and SPRY2 in the carcinoma tissues was positively correlated $\left(r^{2}=0.658, P<0.001\right)$ moderately strongly, i.e. cancers with low expression of $S P R Y 2$ also displayed low expression of SPRY1. This indicates that down-regulation typically affects both $S P R Y$ genes in parallel, although in the case of SPRYI it is typically modest.
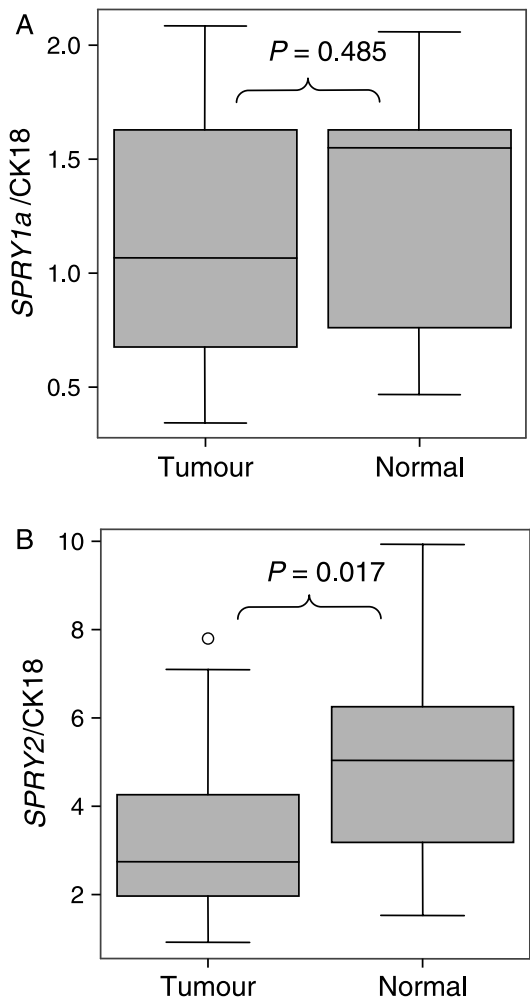

Figure 2 Real-time RT-PCR analysis of SPRY expression in 49 macrodissected prostate cancer tissues. Box plot representation of SPRY1 (A) and SPRY2 (B) mRNA expression levels adjusted to CK18 mRNA.
Mean expression of SPRYIa as well as $S P R Y 2$ was significantly lower in patients experiencing biochemical recurrences during the average follow-up period of 66 months (Fig. 3). Expression of both genes tended to be lower in advanced stage cancers and in cases with lymph node metastases, although the difference did not reach statistical significance (Fig. 3). No association with pre-operative serum levels of prostate specific antigen and Gleason score (data not shown) was found.

\section{SPRY2 is specific to epithelial cells in the prostate}

To further ensure that the observed changes were specific to the epithelial component of the prostate, SPRY protein expression was investigated by immunohistochemistry. After testing commercially available antibodies in Western blot analyses we found only one antibody against SPRY2 (see Methods and materials) that was sufficiently specific, as it yielded a single band of the expected $35 \mathrm{kDa}$ molecular mass (data not shown). Using this antibody, SPRY2 was found localized in prostate sections predominantly in the cytoplasm of basal cells of the glands (Fig. 4A, arrows), while secretory cells showed a weaker and more heterogeneous staining pattern and the mesenchymal compartment remained almost unstained (Fig. 4A). Prostate cancer specimens retained staining in the epithelial compartment, at a staining intensity similar to that in normal glands (Fig. 4B). This finding supports the RT-PCR data, since the moderate decreases found at the mRNA level are unlikely to result in protein changes detectable by immunohistochemistry.

\section{All SPRY mRNAs are expressed in prostate cancer cell lines}

The expression of SPRYIa and SPRY2 and, in addition, that of the alternative splice form SPRYIb was also determined in prostate cancer cell lines (Fig. 5). Normal urothelial cells proliferating in primary culture were used as a control. All three messages were detectable in the prostate cancer cell lines. Whereas $S P R Y 1 b$ and SPRY2 mRNA were detectable at similar or higher levels compared to normal cells, the level of SPRY1a mRNA was somewhat lower in three prostate carcinoma lines (except PC3) than in normal cells.

\section{The alternative splice forms of SPRY1 are not independently expressed}

Although the ratio of the two alternative SPRYI mRNAs differed among the prostate carcinoma cell lines, both forms were detected. We further compared 

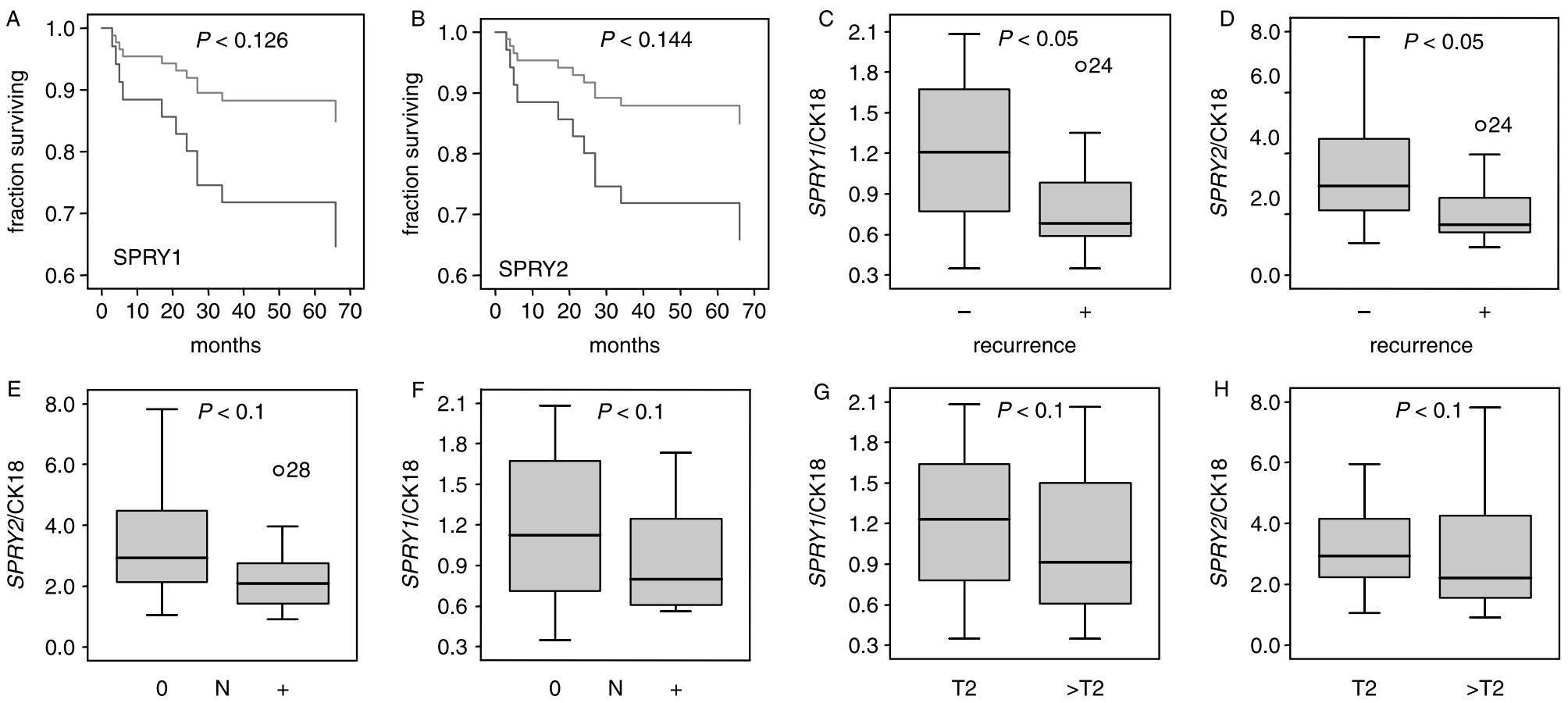

Figure 3 Relationship of $S P R Y$ expression to clinical parameters in prostate cancer. (A, B) Cox regression analysis of the relationship of $S P R Y$ expression (> vs $<$ median) to biochemical recurrence after prostatectomy. (C, D) SPRY expression in cases without $(-)$ or with $(+)$ biochemical recurrence. (E, F) Relationship of $S P R Y$ expression to lymph node metastasis. $(G, H)$ Relationship of $S P R Y$ expression to tumour stage. 


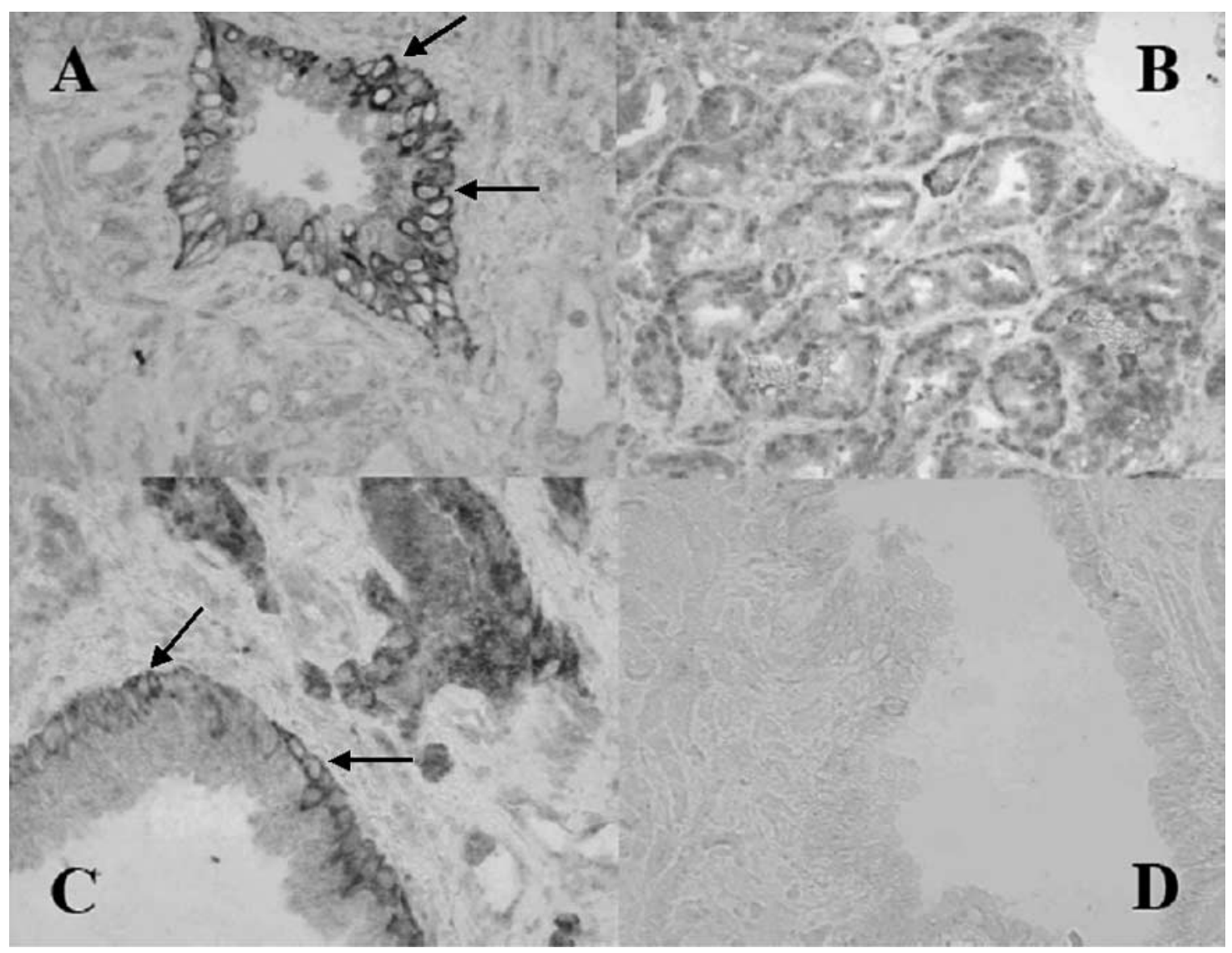

Figure 4 Immunohistochemical analysis of SPRY2 expression in prostate cancer. Double staining was used for SPRY2 (dark grey) and the basal cell marker $34 \beta 2$ (black). (A) Normal gland; (B) carcinoma; (C) normal gland adjacent to carcinoma; (D) negative control. Note similar levels of expression in basal cells of normal glands (arrows) and carcinoma, and lower staining intensity in secretory cells. Stromal cells are very weakly stained.

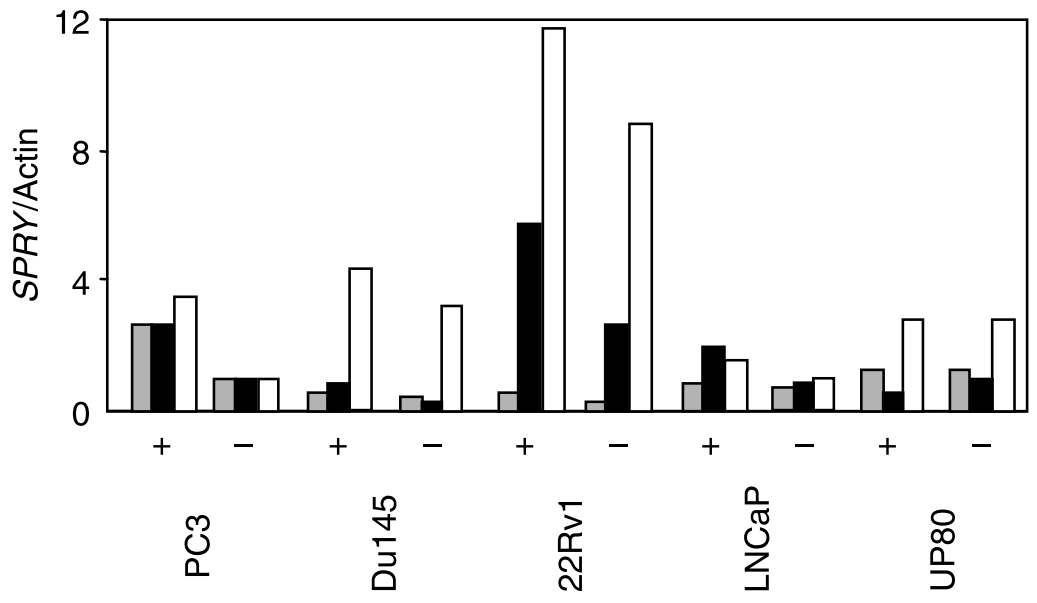

Figure $5 S P R Y$ expression in prostate cancer cell lines. Expression of SPRY1a (grey bars), SPRY1b (black bars), and SPRY2 (white bars) mRNA determined by real-time RT-PCR in four prostate carcinoma cell lines and cultured normal uroepithelial cells under normal growth conditions $(-)$ and following 3 days of treatment with $2 \mu \mathrm{M} 5$-aza-dC $(+)$. 
the expression of the two SPRY1 mRNA splice forms in various normal genitourinary tissues and cells. Their expression correlated positively and moderately well $\left(r^{2}=0.60\right)$ with each other (data not shown).

\section{SPRY promoter methylation shows few changes in prostate cancer}

Since genes hypermethylated in cancer can often be induced by DNA methyltransferase inhibitors, the prostate carcinoma cell lines were treated with 5-aza$\mathrm{dC}$ at an active but non-toxic concentration (Hoffmann et al. 2005). This treatment led only to small increases, none of them more than 2.5-fold (Fig. 5). In particular, the strongest increase in SPRYla expression was observed in PC3, which had the strongest expression before treatment.

Additionally, DNA methylation was investigated by bisulphite sequencing in a region near the transcriptional start sites of SPRYIa and SPRY2 each. Three prostate carcinoma cell lines were compared to normal leukocyte samples and normal prostate tissue.

SPRY2

(151bp)

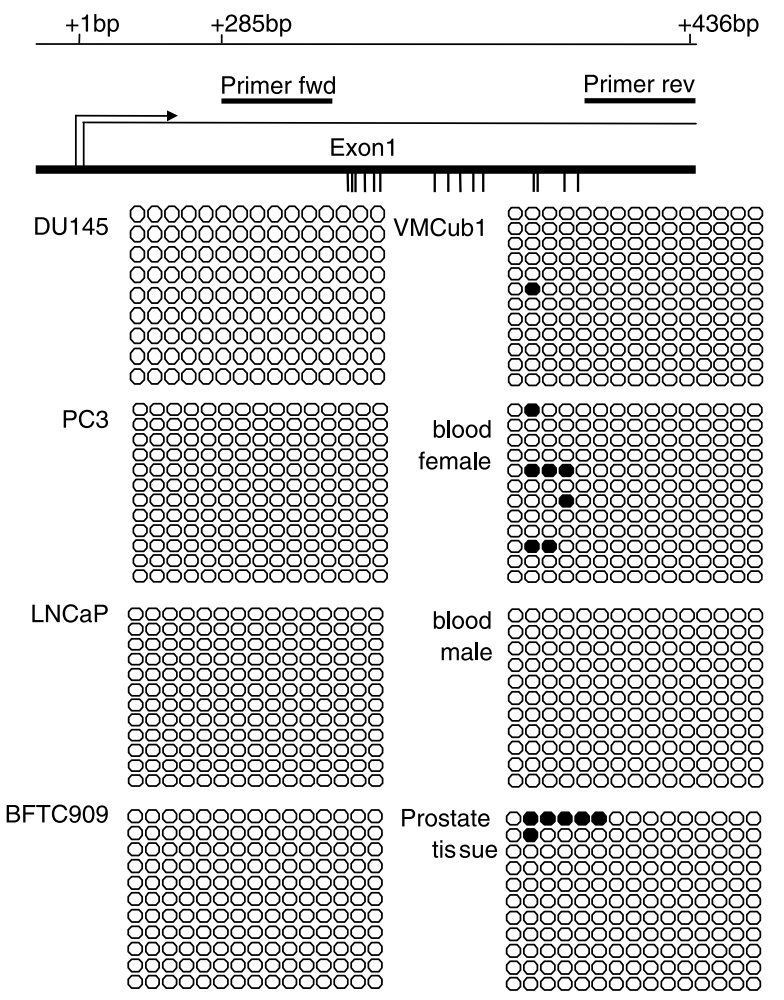

The SPRYla promoter contains only a single $\mathrm{CpG}$ site located close to the transcriptional start site, but twelve sites in the first exon (Fig. 6). These were found to be largely, but not completely, methylated in normal leukocytes and prostate tissue. In three cell lines differing in expression levels (cf. Fig. 5), moderate differences in methylation were discernible. In particular, DU145 presented the lowest level of methylation, while the sequence was fully methylated in LNCaP. Intermediate levels were found in the PC3 line, which exhibits the highest mRNA level (cf. Fig. 5).

In contrast to SPRY1, the SPRY2 gene contains a large $\mathrm{CpG}$-island encompassing the promoter and first exon, which according to the most recent VEGA annotation comprises $1161 \mathrm{bp}$. We analysed a segment near the $5^{\prime}$-end of this CpG-island in which methylation differences had been reported previously (McKie et al. 2005). A few sites were found methylated in individual alleles of normal prostate tissue and a female leukocyte sample, whereas the sequence was entirely devoid of methylation in three prostate carcinoma cell lines investigated (Fig. 6). Surprisingly,

SPRY1a

(319bp)

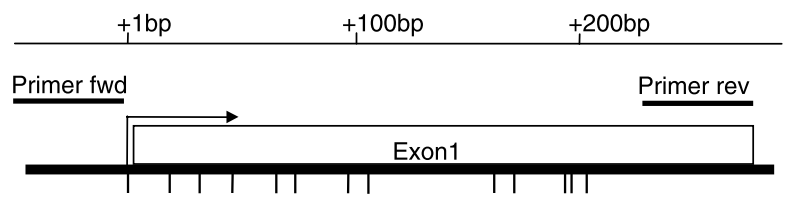

DU145
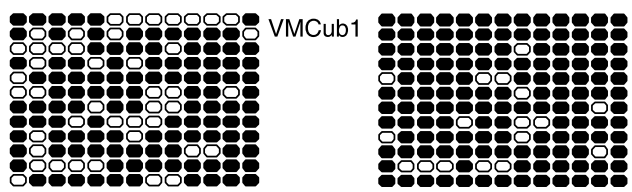

PC3
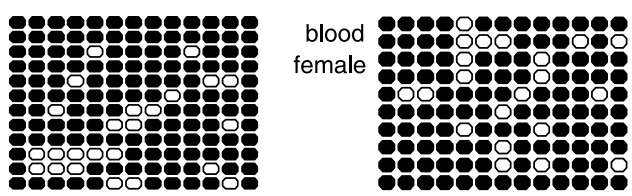

LNCaP
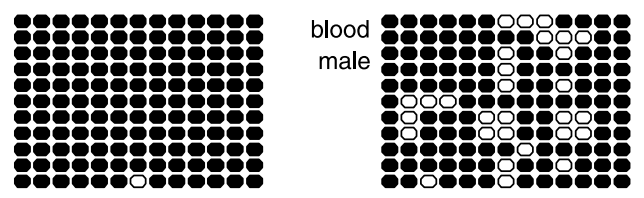

BFTC909
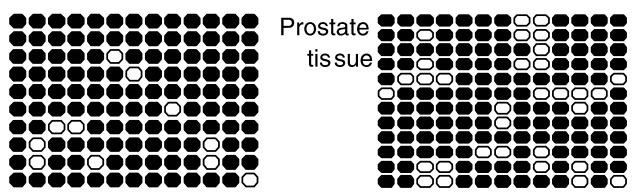

Figure 6 DNA methylation analysis of SPRY1a and SPRY2. Bisulphite sequencing analysis of SPRY1 exon 1a including the single CpG-site in the basal promoter (left) and a CpG-rich region in SPRY2 exon 1 (right). CpG-sites are indicated at the top; black symbols denote methylated and white symbols unmethylated sites; 9-12 alleles from each sample are shown. 
a series of 5 prostate carcinoma tissues with low $S P R Y 2$ expression levels lacked significant methylation as well (Fig. 6) Importantly, with one exception, these specimens had been observed to exhibit significant hypermethylation in GSTP1, RARB2, APC and RASSF1A (Florl et al. 2004).

\section{Discussion}

We observed diminished expression of both SPRY1 and SPRY2 mRNAs in microarray analyses of microdissected prostate carcinoma specimens and confirmed this change for SPRY2 in a larger series of macrodissected tumours compared to normal tissues. Thus, in general, our data confirm two other reports on SPRY1 (Kwabi-Addo et al. 2004b) and SPRY2 (McKie et al. 2005) down-regulation in prostate cancer. Importantly, we found that the decrease in the expression of the two genes is typically co-ordinate. On a note of caution, the decreases were quite moderate in many cases. The previously reported difference in SPRY2 mRNA expression between cancerous and normal prostate expression (11 normal and 31 cancer specimens) was 8-fold (McKie et al. 2005), whereas we found a significant, but only on average 2 -fold, decrease in mRNA expression. Changes of this magnitude at the protein level are difficult to detect by immunohistochemistry, likely accounting for our results with a SPRY2 antibody. However, since SPRY expression is also regulated at the protein level (Egan et al. 2002), mRNA levels do not necessarily parallel protein expression. We could not confirm the decrease in SPRY1 protein expression reported previously in a tissue microarray containing 407 specimens using a rabbit antibody supplied by Upstate Biotechnology (Kwabi-Addo et al. 2004b), because we could not obtain an antibody sufficiently specific for immunohistochemistry. In fact, the 'SPRY'-antibody available from Upstate Biotechnology was raised against SPRY2. This may mean that the data in the previous publication may reflect changes in SPRY2 expression or expression of SPRY proteins overall. The decrease in SPRY1 mRNA expression reported by Kwabi-Addo $e t$ al. in 8 normal and 16 cancer specimens was only 2 -fold on average, in line with our results showing smaller changes (1.5-fold) for SPRY1 than for SPRY2. Thus, in spite of quantitative differences, the three studies, taken together, indicate that a concomitant, albeit often moderate, down-regulation of SPRY1 and SPRY2 takes place in many prostate cancers.

A factor potentially confounding expression analyses of SPRY1 is the presence of the alternative splice form $S P R Y 1 b$, which shares the coding exon 2 (Wang et al. 2003). It was postulated to represent a fetal isoform of the transcript, but our analyses show it to be expressed in several adult tissues and cell lines generally in parallel with the standard RNA form. In prostate carcinoma cell lines, $S P R Y 1 b$ expression also remained detectable. If the alternative mRNA is translated at the same efficiency as the standard transcript, its presence would tend to further buffer any changes in $S P R Y 1$ expression. Since $S P R Y 1 b$ is not simply the fetal isoform of SPRYIa, its physiological function deserves further investigation, e.g. whether the two promoters respond differently to growth factor stimulation.

In prostate cancer, DNA hypermethylation of promoter $\mathrm{CpG}$-islands is a particularly frequent mechanism responsible for the down-regulation of tumour suppressors and other genes (Florl et al. 2004, Kang et al. 2004, Yegnasubramanian et al. 2004). Accordingly, each of the prostate carcinoma cell lines and cancer tissues investigated here contains multiple aberrantly methylated $\mathrm{CpG}$-islands in genes like GSTP1, RARB2, APC and RASSF1A. Nevertheless, no indication was obtained for a major function of DNA methylation in down-regulation of SPRY genes. SPRY1 does not contain CpG-islands at its promoters. Several CpG-sites in exon 1a were predominantly methylated in normal tissue and leukocytes as well as in two prostate carcinoma cell lines. Interestingly, the sequence was almost completely methylated in LNCaP displaying the lowest expression level. Increased methylation in this cell line could be a consequence, rather than a cause, of decreased expression, as observed in a number of similar cases (Chen \& Riggs 2005). Increased methylation of the SPRY2 CpG-island had been reported in prostate carcinomas (McKie et al. 2005). In contrast, we could neither detect any methylation of this sequence in prostate carcinoma cell lines by bisulphite sequencing nor any significant induction by the DNA methylation inhibitor 5-aza-dC by quantitative RT-PCR. According to our data, downregulation of SPRY2 in prostate cancers occurs independently of DNA methylation, as previously reported for breast cancers (Lo et al. 2004). The discrepancies may relate to the tendency of techniques used for bisulphite treatment and methylation detection to yield false positive results. Moreover, most of the sites found hypermethylated by McKie et al. are located at the $3^{\prime}$-end of the CpG-island in a segment extending into intron 1.

In conclusion, the present study confirms and extends previous reports on down-regulation of SPRY genes demonstrating concomitant down-regulation and a significant association with recurrence underlining the 
importance of these changes. However, it should be cautioned that the decreases in expression might be quite modest and appear not to be accompanied by promoter hypermethylation. Therefore, it remains to be investigated to what extent down-regulation is mediated by changes in chromatin structure, e.g. histone methylation, and which signals regulate the $S P R Y$ gene promoters in normal and cancerous prostate epithelial cells.

\section{Acknowledgements}

The authors wish to dedicate this paper to the memory of Dr. Manfred Hergenhahn, who initiated the collaboration between our groups. We are grateful to Dr. M.V. Cronauer for performing initial experiments and to Ms C Hader for technical assistance. This study was supported by the Deutsche Krebshilfe (70-3193 Schu I). The authors declare that there is no conflict of interest that would prejudice the impartiality of this study.

\section{References}

Blackledge G 2003 Growth factor receptor tyrosine kinase inhibitors; clinical development and potential for prostate cancer therapy. Journal of Uroloy 170 77-83.

Bloethner S, Chen B, Hemminki K, Müller-Berghaus J, Ugurel S, Schadendorf D \& Kumar R 2005 Effect of common B-RAF and N-RAS mutations on global gene expression in melanoma cell lines. Carcinogenesis $\mathbf{2 6}$ 1224-1232.

Chen ZX \& Riggs AD 2005 Maintenance and regulation of DNA methylation patterns in mammals. Biochemistry \& Cell Biology 83 438-448.

Chi L, Zhang S, Lin Y, Prunskaite-Hyyryläinen R, Vuolteenaho R, Itäranta P, Prunskaite-Hyyryläinen R, Vuolteenaho R, Itäranta P et al. 2004 Sprouty proteins regulate ureteric branching by coordinating reciprocal epithelial Wnt11, mesenchymal Gdnf and stromal Fgf7 signalling during kidney development. Development 131 3345-3356.

Chomczynski P \& Sacchi N 1987 Single-step method of RNA isolation by acid guanidinium thiocyanate-phenolchloroform extraction. Analytical Biochemistry 162 156-159.

Christofori G 2003 Split personalities: the agonistic antagonist Sprouty. Nature Cell Biology 5 377-379.

Cohen CD, Gröne H-J, Gröne EF, Nelson PJ, Schlöndorff D \& Kretzler M 2002 Laser microdissection and gene expression analysis on formaldehyde-fixed archival tissue. Kidney International 61 125-132.

Cronauer MV, Schulz WA, Seifert HH, Ackermann R \& Burchardt M 2003 Fibroblast growth factors and their receptors in urological cancers: Basic research and clinical implications. European Urology 43 309-319.
Cui X \& Churchill GA 2003 Statistical tests for differential expression in cDNA microarray experiments. Genome Biology 4210.

Djakiew D 2000 Dysregulated expression of growth factors and their receptors in the development of prostate cancer. Prostate 42 150-160.

Egan JE, Hall A, Yatsula BA \& Bar-Sagi D 2002 The bimodal regulation of epidermal growth factor signalling by human sprouty proteins. PNAS 9 6041-6046.

Florl AR, Steinhoff C, Müller M, Seifert HH, Hader C, Engers R, Ackermann R \& Schulz WA 2004 Coordinate hypermethylation at specific sites in prostate carcinoma precedes LINE-1 hypomethylation. British Journal of Cancer 91 985-994.

Gross I, Bassit B, Benezra M \& Licht JD 2001 Mammalian Sprouty proteins inhibit cell growth and differentiation by preventing Ras activation. Journal of Biological Chemistry 276 46460-46468.

Hacohen N, Kramer S, Sutherland D, Hiromi Y \& Krasnow MA 1998 Sprouty encodes a novel antagonist of FGF signalling that patterns apical branching of the Drosophila airways. Cell 92 253-263.

Hanafusa H, Torii S, Yasunaga T \& Nishida E 2002 Sprouty1 and Sprouty2 provide a control mechanism for the Ras/MAPK signalling pathway. Nature Cell Biology 4 850-858.

Hoffmann M, Florl A, Seifert HH \& Schulz WA 2005 Multiple mechanisms downregulate CDKN1C in human bladder cancer. International Journal of Cancer 114 406-413.

Kang GH, Lee S, Lee HJ \& Hwang KS 2004 Aberrant CpG island hypermethylation of multiple genes in prostate cancer and prostatic intraepithelial neoplasia. Journal of Pathology 202 233-240.

Kenzelmann M, Klaren R, Hergenhahn M, Bonrouhi M, Grone HJ, Schmid W \& Schutz G 2004 High-accuracy amplification of nanogram total RNA amounts for gene profiling. Genomics 83 550-558.

Kwabi-Addo B, Ozen M \& Ittmann M 2004a The role of fibroblast growth factors and their receptors in prostate cancer. Endocrine-Related Cancer 11 709-724.

Kwabi-Addo B, Wang J, Erdem H, Vaid A, Castro P, Ayala G \& Ittmann M 2004b The expression of Sprouty1, an inhibitor of fibroblast growth factor signal transduction, is decreased in human prostate cancer. Cancer Research 64 4728-4735.

Li X, Brunton V, Burgar H, Wheldon L \& Heath J 2004 FRS2-dependent SRC activation is required for fibroblast growth factor receptor-induced phosphorylation of Sprouty and suppression of ERK activity. Journal of Cell Science 117 6007-6017.

Lo T, Yusoff P, Fong CW, Guo K, McCaw BJ, Phillips WA, Yang H, Wong ES, Leong HF, Zeng Q et al. 2004 The Ras/mitogenactivated protein kinase pathway inhibitor and likely tumor suppressor proteins, Sprouty 1 and Sprouty 2 are deregulated in breast cancer. Cancer Research 64 6127-6136.

McKie A, Douglas D, Olijslaers S, Graham J, Omar M, Heer R, Gnanapragasam V, Robson C \& Leung H 2005 Epigenetic inactivation of the human sprouty2 (hSPRY2) homologue in prostate cancer. Oncogene 24 2166-2174. 
Swiatkowski S, Seifert HH, Steinhoff C, Prior A, Thievessen I, Schliess F \& Schulz WA 2003 Activities of MAPkinase pathways in normal uroepithelial cells and urothelial carcinoma cell lines. Experimental Cell Research 282 48-57.

Wang L, Ji C, Wu H, Xu J, Wu Q, Dai J, Yin G, Ye X, Gu S \& Xie Y 2003 Identification and expression analysis of a novel splice variant of human Sprouty 1 gene. International Journal of Molecular Medicine 12 783-787.

Wong E, Fong C, Lim J, Yusoff P, Low B, Langdon W \& Guy G 2002 Sprouty2 attenuates epidermal growth factor receptor ubiquitylation and endocytosis, and consequently enhances Ras/ERK signalling. EMBO Journal 21 4796-4808.

Yegnasubramanian S, Kowalski J, Gonzalgo ML, Zahurak M, Piantadosi S, Walsh PC, Bova GS, De Marzo AM, Isaacs WB \& Nelson WG 2004 Hypermethylation of CpG islands in primary and metastatic human prostate cancer. Cancer Research 64 1975-1986.

Yusoff P, Lao D, Ong S, Wong E, Lim J, Lo T, Leong H, Fong C \& Guy G 2002 Sprouty2 inhibits the Ras/MAP Kinase pathway by inhibiting the activation of Raf. Journal of Biological Chemistry 277 3195-3201. 